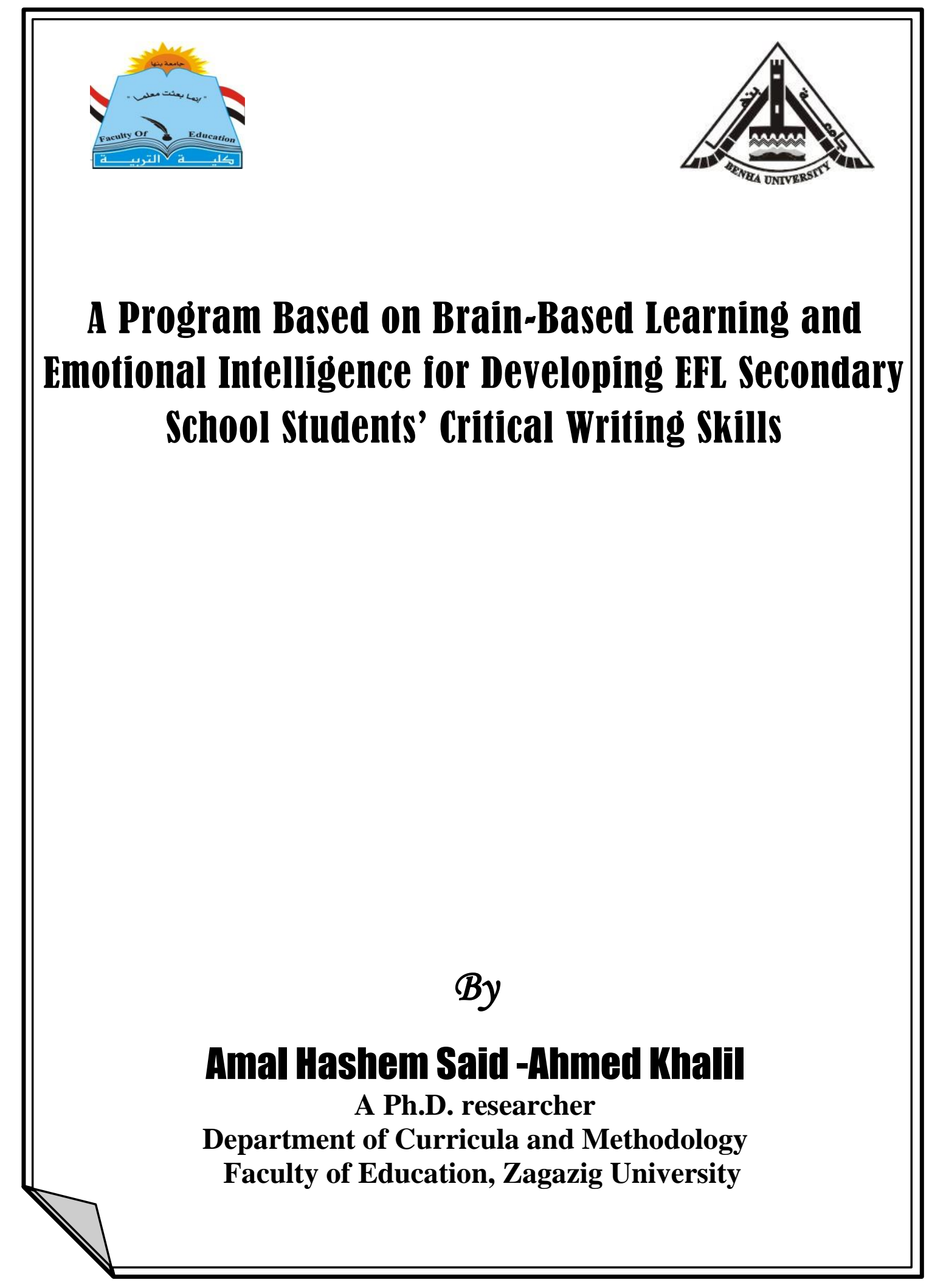




\title{
A Program Based on Brain-Based Learning and Emotional Intelligence for Developing EFL Secondary School Students' Critical Writing Skills
}

\author{
By \\ Amal Hashem Said -Ahmed Khalil \\ A Ph.D. researcher \\ Department of Curricula and Methodology \\ Faculty of Education, Zagazig University

\section{Abstract}

The present study aimed at investigating the effect of a program based on brain-based learning and emotional intelligence on developing some EFL critical writing skills of secondary school students. The quasiexperimental design was adopted. Fifty students (first-year secondary stage) participated in this study. They were randomly drawn from Gamal Abdel Nasser secondary school for Girls in Zagazig, Sharqiyah Governorate and equally divided into an experimental group and a control group. An EFL critical writing test, and a program based on brain-based learning and emotional intelligence were designed by the researcher. The program was conducted in the first term of the academic year 2018/2019 and lasted for seven weeks, three sessions a week. The students of the control group received the regular instruction. By the end of the experimentation, the critical writing test was administered to the experimental and control groups. The scores of the experimental and control groups were compared and analyzed. Also, the pre and post scores of the experimental group were compared and analyzed. The results of the study indicated that: (i)the experimental group surpassed the control in the post administrations of the EFL critical writing test, (ii) the experimental group did better in the post administrations of the critical writing test than in the pre -administration. Therefore, it could be concluded that the program based on brain-based learning and emotional intelligence had a positive effect on developing EFL critical writing skills of secondary school students.

Key- words: Brain -based learning, Emotional intelligence, Critical writing skills, Secondary stage. 


\section{الملخخــص}

هدفت الدراسـة الحالية إلى الاستقصساء عن استخدام برنامج قائم على التعلم المستتد للدماغ والذكاء الوجداني في تتميـة مهارات الكتابـة الناقدة باللغـة الإنجليزيـة كلغـة أجنبيـة لدى هـ طلاب المرحلة الثانويسة. وتكونت عينـة الدراسـة من خمسين طالبـة في الصف الاول الثانوي، حيث تم تقسيمهم إلى مجموعـة تجريبية (خمس وعشرون طالبـة) ومجموعـة ضـابطة (خمس وعشرون طالبـة). وقد قامت الباحثة بتصميم اختبار للكتابـة الناقدة وكذللك برنـامج قائم على التعلم المسـتند للـدماغاغوالـكاء الوجـداني في تتميـة مهـارات الكتابـة الناقدة باللغـة الإنجليزيـة للمجموعة التجريبية، وتم تطبيق البرنامج للمجموعة التجريبية في الفصل الدراسي الاول للعام

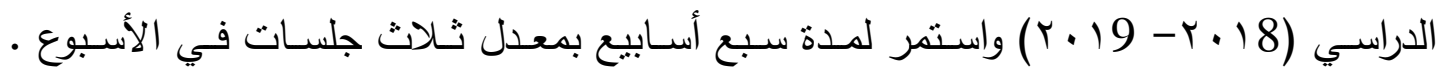
وبنهاية التجربة العملية تم توزبع اختبار الكتابة الناقدة لكل من المجموعتين الضـابطة والتجربيية لمعرفة مدى الاختلاف في مهارات الكتابة الناقدة باللغة الإنجليزية بعد استخدام البرنامج القائم

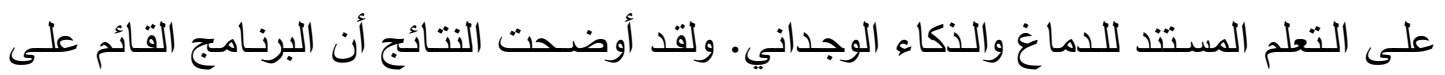
التعلم المستتد للدماغ والذكاء الوجداني فعال في تتمية مهارات الكتابة الناقدة باللغة الإنجليزية لطلاب المجموعة التجريبية. الكلمات المفتاحية: برنامج قائم على التعلم المستتد للدماغ والذكاء الوجداني - مهارات الكتابة الناقدة باللغة الإنجليزية. 


\section{Introduction}

The ability to write in English as a foreign language is necessary for learners around the world. Not only mastering the basic writing skills is important, but also the critical ones. That is recommended by the Ministry of Education Directives (2018/2019) for English Language Syllabus at the Secondary Stage while stressing the importance of developing the students' critical thinking skills. The key to mature writing is learning to write critically. Without criticism, texts that you read have no life beyond that of the author.

Ahangari and Sepehran (2014) indicated that critical thinking and writing are to be thought of as skills and students have to acquire these skills in order to learn how to reason and argue logically and how to face a problem from various perspectives. To Braun (2014), critical writing includes students' ability to develop perspectives on the work of others. This act is considered akin to critical thinking that is often advocated for our students, but more refined.

Despite the importance of critical writing for EFL students, teaching writing critically has been undervalued and reluctance to participate in writing activities is observed in students' behavior; besides, critical thinking skills gained by EFL students seem to be unsatisfactory. Stapleton (2002) and Alagozlu (2007) declared that EFL students lack critical thinking. They cannot express their own ideas in EFL writing because of their low critical thinking skills. They emphasized that critical pedagogy is really needed in EFL writing classes.

Brain-based learning (BBL) can build expressive language skills of EFL students. According to Jensen (2000), brain-based learning is learning in accordance with the way the brain is naturally designed to learn. It is an instructional approach that integrates findings about what facilitates accelerated learning. Haghighi (2012) stated that brain- based learning theory focuses on using research about how the brain works (neuroscience) and how teachers can use this knowledge to help students learn English quickly and efficiently. Jensen (2008) added that brain- 
based learning is a set of principles and a base of knowledge and skills upon which we can make better decisions about the learning process.

Jackson (2003) assured that brain- based learning strategies can yield significant and measurable benefits in terms of student performance outcomes. Al Shamary and Al-Hashmy(2018) revealed that brain based learning is approved to effective for developing students writing skills .It is an approach that creates a positive interaction, and secured safe environment, thus encouraging students to think freely and enhances their abilities to think critically in their writing.

Emotional intelligence (EI) is considered an umbrella term of habits, skills, attitudes, and nature. It is considered one of the most important factors which contribute to the foreign language learning. According to Salar and Oroji (2017), EI has an important role to play in strengthening communication skills when certain EI elements are enhanced in the student. If the students have been introduced to the power of emotional intelligence, they likely would be able to effectively handle anxieties, shyness, anger, fear and the stresses of learning difficulties. Ghanizadeh and Moafian (2011) and Afshar and Rahimi (2014) assured that certain components of emotional intelligence such as assertiveness, social responsibility, and flexibility are positive predictors of critical thinking. Emphasizing the impact of EI on writing, Karimi (2012) stated that students' understanding and managing their own emotions and being aware of and responsive to others' emotions would contribute to the $\mathrm{L} 2$ productive skills, particularly writing.

In conclusion, it can be said that using brain -based learning and emotional intelligence has an essential role in improving critical thinking skills, motivating students to write and creating an emotional environment enriched with a variety of strategies which stimulate students to write critically.

\section{Context of the problem}

Being a teacher of English, the researcher has noticed that no enough interest was given to EFL critical writing skills despite their great importance. The problem of this study can be stated in the poor performance of the first-year secondary stage students in the EFL critical 
writing skills; therefore, this study is an attempt to develop the EFL students' critical writing skills using a program based on brain-based learning and emotional intelligence.

\section{Questions of the study}

In order to tackle this problem, the present study was an attempt to address the following main question:

"What is the effect of the program based on brain-based learning and emotional intelligence on developing EFL first-year secondary school students' critical writing skills?"

The following sub- questions have been derived:

1- What are the necessary critical writing skills needed for EFL firstyear secondary stage students?

2- What are the actual levels of the EFL first-year secondary stage students in the critical writing skills?

3- What is the framework of the program based on brain-based learning and emotional intelligence for developing EFL first-year secondary stage students' critical writing skills?

\section{Aims of the study}

\section{This study aimed at:}

1- Developing the necessary critical writing skills of the EFL firstyear secondary school students.

2- Designing a program based on brain-based learning and emotional intelligence for developing EFL first-year secondary stage students' critical writing skills.

\section{Significance of the study}

\section{This study was hoped to be of significance to:}

1- The EFL first-year secondary school students: It can give those students a chance to develop their critical writing skills.

2- EFL teachers of English: This study can help those teachers to understand how to adopt the strategies, activities and skills involved in the program for improving EFL critical writing skills. 
3- Curriculum developers and designers: This study can provide a model of a program based on BBL and EI to help in the instruction of EFL critical writing skills.

4- EFL researchers: This study can pave the way for other researchers to conduct further studies on BBL and $\mathrm{EI}$ in the EFL context.

\section{Delimitations of the study}

\section{The study was delimited to:}

1- The participants were secondary stage students in public schools. That is because students in these schools are not trained well to write critically in English.

2- The study was delimited to using one instrument which is an EFL critical writing test.

3- Developing some EFL critical writing skills which were approved by the jury members to be suitable to the participants.

\section{Procedures of the study}

\section{The current study adopted the following procedures:}

1- Surveying literature and previous studies related to brain-based learning, emotional intelligence and EFL critical writing skills.

2- Preparing a list of EFL critical writing skills and consulting several experts to select the appropriate ones.

3- Constructing the pre-posttest of critical writing and submitting it to the jury members to identify its validity

4- Administering the EFL critical writing test to both groups to identify the students' real level concerning the identified EFL critical writing skills.

5- Designing the program based on brain-based learning and emotional intelligence; intended to develop the EFL students' critical writing skills.

6- Implementing the program based on brain-based learning and emotional intelligence to the experimental group by the researcher; aiming at developing their EFL critical writing skills; while the control group received the regular instruction. 
7- Administering the EFL critical writing test to both groups to investigate the effect of the program based on BBL and EI on developing the EFL critical writing skills.

8- Comparing the results of the control and the experimental groups regarding the post administrations of the test and then analyzing them statistically.

9- Comparing the results of the pre to post administrations of the experimental group and analyzing them statistically.

10- Interpreting the results and discussing them.

11- Providing conclusions, recommendations and suggestions.

\section{Definition of terms}

\section{Brain -based learning (BBL):}

To Jensen (2016), Brain -based learning is the engagement of strategies based on the principles derived from an understanding of the brain to enhance students' achievement.

Operationally. Brain-based learning is an umbrella term which includes a variety of teaching methods, strategies, activities, techniques that consider the cognitive, emotional, and kinesthetic aspects of the first- year secondary school to develop their EFL critical writing skills.

\section{Emotional Intelligence (EI)}

Bar-On (2006) defined it as a cross-section of interrelated emotional and social competencies, skills and facilitators that determine how effectively we understand and express ourselves, understand others and relate with them, and cope with daily demands.

Operationally. Emotional intelligence is a set of emotional and social competencies and skills which are acquired and learnt by the firstyear secondary school students to manage and regulate their emotions properly to overcome their fear and hesitation in order that they could be able to write critically.

\section{Eritical Writing:}

Writing critically means presenting your conclusions in a clear and well-reasoned way to persuade others. It is the result of an ongoing 
process of reflecting, researching, note-making, reading and writing. It means you do not accept information at face value (Aksu Ataç,2015).

Operationally. Critical writing is a form of writing in which the first- year secondary stage students are able to present their reasoning and evidence in a clear, well -structured manner to give opinion, provide a reasonable evidence to support point of view, make comparisons, provide causes and effects, make a prediction, and give appropriate solutions for a problem.

\section{Review of literature}

\section{Critical thinking in EFL writing:}

Critical writing can't be separated from critical thinking. There is a close relation between them. Kruchin (2016) viewed critical writing as a form of critical thinking, which corresponds to the more general assumption that writing is thinking. She mentioned that developing ideas in writing is the greatest problem that students face. Students can learn language rules, vocabulary words, and even how to structure essays. Learning how to develop ideas in writing; in other words, the ability to think clearly and form a judgment is what proves most difficult for them. Al Sharadgah (2014) mentioned that writing is a vehicle through which students can express their critical thinking when students are trained to use critical thinking methods consistently in writing.

Liaw (2007) and Barnawi (2011) concurred that the concept of critical thinking in L2 writing is defined as an ability to analyze facts, produce and organize ideas, maintain opinions, make comparisons, judge arguments, and solve problems by the use of existing information, previous knowledge, experience, and world knowledge when writing. They added that student writers are expected to attain the ability to think critically as they go through process-oriented activity.

El-Attar (2013) indicated that the critical quality of writing includes at least three characteristics:

1- Writing requires students to do not report information but also evaluate it. 
2- Students are expected to make judgments. Evaluating some information should be supported by recommendations or solutions.

3- Students are expected to be more thorough and more precise; to do this, students need to have more one piece of evidence and information, to use more than one source to look at the things more than one way.

\section{Teaching critical writing:}

Critical writing is not necessarily writing about the topic in a negative way; it is simply making sure that you have considered all sides of the argument. AKSU Ataç (2015) emphasized the need for critical writing in higher education more than descriptive texts. The learner should have to analyze and evaluate as well and needs to justify and give evidence for his/her claims, suggests what other points of view there are and evaluates them. When the learner writes critically, they will compare and contrast argument and ideas; they will find advantages and disadvantages of solutions and problems and provide evidence and support for their points of view.

University of Bradford (n.d) suggested some steps to be followed when writing critically:(a) Employing critical thinking -by asking questions of the origins of ideas, the assumptions behind the ideas, and the applicability of the ideas. Evidencing your conclusions and findings from this questioning process and keeping an open mind about the application of this knowledge to address a problem or answer a question. (b)Importance of pre-writing. In this step you will begin by analyzing the question, or problem and ending with proofing and submitting. (c) Constructing critically analytic text: taking a position. When you write a piece of critically analytic text, you will have to decide about what angle or point of view you want to take. (d)forming a line of reasoning that your thinking is coherently following.

\section{Principles and strategies of Brain-Based learning.}

Brain-based learning principles stemmed from neurological research, particularly during the 1990s. Educators and psychologists such as (Caine and Caine, 2006); (Boyatzis, Goleman, 
and Rhee, 2000); (Jensen, 2000, 2008) are pioneers as well as forerunners in the BBL movement. These authors have helped with disseminating neurological research into research-based academic best practices. According to Caine et al.,(2015), the following are the twelve principles of brain-based learning; (i) the brain is a parallel processor, (ii) learning engages the entire physiology, (iii) the search for meaning is innate, (iv) the search for meaning occurs through patterning, (v) emotions are critical to patterning., (vi) the brain processes parts and wholes simultaneously, (vii) learning involves both focused attention and peripheral perception, (viii) learning always involves conscious and unconscious processes, (ix) We have at least two different types of memory, (x) learning is developmental, (xi) learning is enhanced by challenge and inhibited by threat, (xii) Each brain is uniquely organized.

Brain-based education is the engagement of strategies based on understanding of the various mechanisms of brain functions, to enhance students' achievement (Marope, 2016; Mayer, 2017). Duman (2006) emphasized the importance of enriching instruction and learning environment using brain-based strategies to accelerate learning. Such strategies include manipulative, active learning, field trips, guest speakers, and real-life projects that allow students to use many learning styles and multiple intelligences. According to Erlauer( 2003) ,these brain-based strategies such as: movement, music, personal stories, humor, metaphors, colors, brainstorming using project presentations should be used in different levels and content areas in class

Tate (2013) added that teachers, as growers of dendrites and synapses should know how students comprehend and retain information. She synthesized 20 instructional strategies that potentiate brain-based learning. These strategies include brain storming, discussion, graphic organizers, visuals, humor, role play, movement, music, storytelling, manipulatives and technology.

All the aforementioned strategies revolve around the following three fundamental instructional methods related to the brain-based learning (Caine et al.,2015) 
1- Relaxed alertness which refers to creating a safe learning environment, to lessen fear and anxiety thus enabling student engagement.

2- Orchestrated immersion in complex experience which indicates giving learners a diverse learning experience that include options and a sense of wholeness.

3- Active processing of experience which includes creating optimal ways to consolidate learning by letting the learners actively practicing it.

\section{Components of Emotional Intelligence}

Success can't be attributed only to the learner's intellectual intelligence level as Zarezadeh (2013) stated that learners' levels of intelligence play a significant role in their English learning; however, their success or failure is not merely limited to the level of intelligence. Recently, psychologists pointed out another type of intelligence which performs a better function than the intelligence quotient in individual's achievement, life and education-that intelligence is called emotional intelligence (EI). According to Goleman (1998), and Cherniss (2000), one can attribute $80 \%$ of the reasons for any success to the emotional intelligence. Consequently, it can be argued that the more an English learner possesses emotional intelligence, the more successful he/she becomes. Salovey, Woolery and Mayer (2001) defined emotional intelligence as a subset of social intelligence that involves the ability to monitor one's own and others' feelings and emotions, to discriminate among them and to use this information to guide one's thinking and actions.

Goleman (1995) identified five components of emotional intelligence: (i) self-awareness which includes knowing what we are feeling at the moment and this provides us with having a realistic assessment of our own abilities and a well-grounded sense of selfconfidence. (ii)self-regulation which includes handling our emotions so that they facilitate the task at hand and being able to delay gratification to pursue goals; moreover, it includes recovering well from emotional 
distress. (iii)motivation which includes using our deepest preferences to move and guide us toward our goals. (iv) empathy which means sensing what people are feeling and being able to take their perspective into consideration. (v) social Skills which pertains to handling emotions in relationships well and interacting smoothly; using these skills to persuade and lead for cooperation and teamwork.

\section{Relationship between Brain-based learning, Emotional intelligence and critical writing}

Wortock (2002) assured that brain -based learning improves critical thinking success. The more the students feel secured in class, the more they are encouraged to participate in writing activities. Furthermore, teachers are required to develop great willingness to appreciate students' efforts in the process of writing because it helps, if they show any kind of progress in the course of their writing and brings them a high level of self -esteem, as well. Wang (2009) added that students who took part in critical thinking English conversation in the form of discussion in class attained better critical thinking skills.

In an attempt to enhance writing via the use of brain -based learning, Al-Shamary and Al-Hashmy (2017) investigated the effect of an educational program based on Jensen's brain -based Learning model on improving the creative writing among preparatory stage students in Saudi Arabia. The study proved that jensen's model had a positive effect on the students' writing performance.

In the Egyptian context, El-Maksoud, and El-Fattah (2016) investigated the effect of some brain- based learning strategies on developing journal writing of prospective teachers at Faculty of Education. The findings revealed that BBL strategies improved students' writing. Critical thinking and emotions are inseparable. According to, Elder (1996), critical thinking provides us with a basis for a rational and reasonable emotional life. At the same time, the affective dimension, comprised of feelings and volition, is a necessary condition and component of high-quality reasoning and problem solving. Every defect in emotion and drive creates a defect in thought and reason. Intelligence on this view requires command of the affective dimension of mind. 
Karimi (2012) stated that students' understanding and managing their own emotions and being aware of and responsive to others' emotions would contribute to the L2 productive skills, particularly writing.

\section{Hypothses}

1- there is a statistically significant difference between the mean scores of the experimental group and the control group in their performance of the post EFL critical writing test in favor of the experimental group.

2- there is a statistically significant difference between the mean scores of the experimental group in their performance of the pre and post administrations of the EFL critical writing test in favor of the post administration.

3- The program based on Brain-based learning and Emotional intelligence would have a positive effect on developing the experimental group studnts'critical writing skills.

\section{Methodology}

\section{1-Participants of the study}

The participants of the study were first year secondary stage students. Fifty female students chosen randomly from Gamal Abdel Nasser secondary school for girls at West Zagazig Zone, Sharqya Governorate. The researcher chose two classes: the first class of (25) as an experimental group and the second of (25) as a control group. To prove the homogeneity between the two groups in critical writing skills, an EFL critical writing test was preadministered to both groups. Then Independent Sample Test was employed to find out any statistical difference.

Table (1)

t-values for the Differences between the Experimental group and the Control Group on Critical Writing pretest

\begin{tabular}{|c|c|c|c|c|c|c|c||}
\hline Skill & Group & $\mathbf{N}$ & Mean & St. Deviation & df & t-value & Sig \\
\hline \multirow{2}{*}{$\begin{array}{c}\text { Overall Critical } \\
\text { Writing Skills }\end{array}$} & Control & 25 & 7.88 & 3.308 & \multirow{2}{*}{48} & \multirow{2}{*}{.302} & .764 \\
\cline { 2 - 8 } & Experimental & 25 & 8.20 & 4.133 & & & \\
\hline
\end{tabular}

$-\mathrm{P}>0.01$ (not significant) 
The above table indicates that there was no statistically significant difference between the experimental group and the control one on the critical writing pre-test. t-value for overall critical writing skills is (0.302) with significance 0.764 . This value is not significant at the level of 0.01 . Hence, both groups were of the same level at the beginning of the experimentation. Thus, any possible improvement after the experimentation would be attributed only to using program based on BBL and EI.

\section{2- Instruments of the study}

To implement the suggested program, an EFL critical writing test (Appendix 1) was designed. To design the critical writing test, an EFL critical writing checklist was a pre- requisite. To grade the EFL critical writing test, an EFL critical writing rubric was a post requisite.

a) The critical writing skills checklist

b) The critical writing test

c) The critical writing rubric

\section{3-The program based on brain-based learning and emotional intelligence.}

The following is a description of the steps the researcher went through to design the current program for the EFL secondary school students:

\section{Content of the program}

The researcher selected a number of various strategies and activities in accordance with brain-based learning and emotional intelligence. Such strategies are Cooperative learning (Think -Write pairshare and Team-Pair-Solo), Brainstorming, Reading aloud, Discussion, Graphic organizers (mind map and Venn diagram, role-paly, humor, authentic material (videos, international newspaper), music, movement. In the core of these strategies and activities, the students learned and acquired some emotional skills that are intrapersonal intelligence skills (self -awareness, independence, motivation), interpersonal intelligence skills (social responsibility, relationship management), empathy, and stress management. The researcher also selected some English songs, 
and pieces of soft music to create a relaxed secured environment. In additions some emotional short stories were selected carefully to enhance their emotional intelligence while reading them aloud and their critical skills as well, they were taken from the following websites:

https://harpers.org/author/harukimurakami/ https://english-magazine.org/english-stories/2027-short-story1121 https://www.wattpad.com/81599041-moral-stories-who-or-what-do-welove-more

https://www.wattpad.com/81599041-moral-stories-who-or-what-do-welove-more https://english-magazine.org/

\section{Procedures and duration of the BBL and $\mathrm{E} I$ based program}

The critical writing pretest was administered to the participants at the beginning of the first term of the academic year 2018/2019, then the researcher applied the program in October and November ( 7 weeks). The whole program consisted of twenty one sessions (three sessions a week). After finishing the experimentation, it was followed by administering the EFL critical writing test.

\section{Data analysis and the results}

The first hypothesis stated that "there is a statistically significant difference between the mean scores of the experimental group and the control group in their performance of the post EFL critical writing test in favor of the experimental group". To validate this hypothesis, independent samples t-test was used. The following table indicates the results of the post administration of the EFL critical writing test to the experimental and control groups

Table (2):

t-Values for the Differences between the Experimental Group and the Control Group on Overall Critical Writing Posttest

\begin{tabular}{|c|c|c|c|c|c|c|c|}
\hline Skill & Group & N & M & $\begin{array}{c}\text { St. } \\
\text { Deviation }\end{array}$ & df & $\begin{array}{c}\text { t- } \\
\text { value }\end{array}$ & Sig \\
\hline $\begin{array}{c}\text { Overall Critical } \\
\text { Writing Skills }\end{array}$ & control & 25 & 8.68 & 3.145 & \multirow{2}{*}{48} & 8.284 & .000 \\
\cline { 2 - 7 } & experimental & 25 & 18.00 & 4.664 & & \\
\hline
\end{tabular}


The second hypothesis stated that "there is a statistically significant difference between the mean scores of the experimental group in their performance of the pre and post administrations of the EFL critical writing test in favor of the post administration". The following table compares the pre and post administrations.

Table (3)

t-Values for the Differences between Pre / Posttest in Critical writing of the experimental Group

\begin{tabular}{|c|c|c|c|c|c|c|c|}
\hline Skill & Group & N & M & $\begin{array}{c}\text { St. } \\
\text { Deviation }\end{array}$ & df & t-value & Sig \\
\hline $\begin{array}{c}\text { Overall Critical } \\
\text { Writing Skills }\end{array}$ & Pre & 25 & 8.20 & 4.133 & \multirow{2}{*}{48} & 14.774 & .000 \\
\cline { 2 - 7 } & Post & 25 & 18.00 & 4.664 & & & \\
\hline
\end{tabular}

The third hypothesis stated that" The program based on Brainbased learning and Emotional intelligence would have a positive effect on developing the experimental group students' critical writing skills". The researcher calculated the effect size by using the paired sample t-test to compare the scores of the experimental group in critical writing subskills and critical writing test as a whole in the pre and the posttest using Cohen's formula.

Table (4):

The Effect Size of the Program in Developing the Overall Critical Writing Skills

\begin{tabular}{|c|c|c|c|c|c|c|c|c|}
\hline $\begin{array}{c}\text { Overall Critical } \\
\text { Writing Skills }\end{array}$ & pre & 25 & 8.20 & 4.133 & & 14.774 & .563 & $\begin{array}{c}1.13 \\
\text { large }\end{array}$ \\
\cline { 2 - 5 }
\end{tabular}

Table (2) indicates that the experimental group surpassed the control group in the post administration of the EFL critical writing test as a whole and its sub skills. According to this result, the first hypothesis was accepted. Table (3) shows that the experimental group did better in the post administration of the critical writing test as a whole and its sub skills than in the pre administration. Thus, the second hypothesis was accepted. Table (4) indicates that the program based on brain-based learning and emotional intelligence was effective in developing the experimental group students' overall critical writing skills and each subskill. Therefore, this provides enough evidence to support hypothesis three. 


\section{Discussion of the results}

The results of the current study verified the three hypotheses. These significant improvements and modifications can be attributed to a variety of causes related to the nature of the program based on brain-based learning and emotional intelligence. The program includes a variety of interesting strategies and activities such as cooperative learning, discussion, brainstorming, mind mapping, considering their emotions during the act of writing. By working in groups, they enjoyed more opportunities to see how their peers think and how to create ideas, as a result their motivation toward writing increased. The participants' interaction with each other within a pleasant environment and a relaxed climate promoted positive feelings towards participating in writing critically. Allowing students to express their opinions freely, respecting students' perspectives, welcoming all seriously offered opinions and beliefs, setting up and maintaining a caring and supportive environment in which students respect each other's responses and experiences, and providing supportive comments which focused on fostering students' discussions and exchanging points of view boosted their critical writing, all these acts promoted the critical stance among the students. In this learning environment, the students had the opportunity to raise questions, argue, defend points, and negotiate, their critical thinking skills were improved, and hence, became motivated to use information contained in emotion to make effective decisions .Furthermore, better performance in the critical writing might due to the ability of the students to manage emotions and handle relationships. Thanks to BBL and EI, students' participation was active and independent. Students who were passive and avoid writing, became active and more engaged in writing critically.

\section{Conclusions:}

In terms of the study achieved results and given the abovementioned interpretations and discussions, it can be concluded that the program based on BBL and EI proved to be effective in developing EFL critical writing skills. It enabled the students' critical writing abilities as they performed better in: giving their opinions frankly, supporting their opinion with reasonable evidences, making comparisons, providing causes and effects, making predictions, give appropriate solutioning to a 
problem, in addition to demonstrating an effective organizational structure and command of written language conventions in their writing. All this success in critical writing can be attributed to training them to use some effective strategies and activities included in the program based on BBL and EI before, during and after writing critically.

\section{Recommendations:}

In the light of the results and the conclusions of the present study, the following can be recommended:

1- Teachers should encourage students to work in dyads and groups to develop the skills of social responsibility, empathy, listening to others, and independence; besides, working cooperatively allows them to gain confidence and get rid of any fears or hesitations to write critically.

2- Teachers should incorporate facts of health such as stress management, nutrition, relaxation and exercise into the learning process

3- Students' responses, ideas, emotions, and different points of view should be respected and fortified to stimulate students to encourage them write critically.

4- EFL teachers should be trained to the implementation of brainbased strategies and emotional intelligence skills to develop critical writing skills among their students.

5- Syllabus designers and textbook writers should develop and design materials and textbooks which incorporate ways of enhancing critical thinking and emotional intelligence.

\section{Suggestions for further research}

The following areas are suggested to further research

1 - Investigating the effectiveness of a program based on brain -based learning (BBL) and emotional intelligence (EI) in developing critical writing skills at different educational stages (elementary, preparatory, university).

2- Investigating the effectiveness of a program based on BBL and EI in developing vocabulary retention, and grammar acquisition.

3- Examining the effectiveness of the program based on BBL and EI in developing creative reading and writing.

4-Investigating the relationship of a BBL and EI to writing apprehension 


\section{References}

AKSU Ataç ,B.,(2015) From Descriptive to Critical Writing: A Study on the Effectiveness of Advanced Reading and Writing Instruction.Procedia - Social and Behavioral Sciences, Volume 199, p. 620-626

Afshar, H. S., and Rahimi, M. (2014) The relationship among emotional intelligence, critical thinking and speaking ability of Iranian EFL learners. Teaching English Language and Literature Society of Iran (TELLSI), 8(1), 31-59.

Ahangari, S., and Sepehran, H. (2014) The Effect of Intertextuality on Iranian EFL Learners' Critical Writing. Iranian Journal of Language Teaching Research, 2(1), 85-98.

Alagozlu, N. (2007). Critical thinking and voice in EFL writing. Asian EFL journal, 9(3), 118-136.

Al-Shamary, W and Al-Hashmy, A .(2018). The Effect of a proposed teaching program based on Jensen's Brain Based Learning Model on Improving Saudi Student>s Creative Writing.Al-Quds journal for Research and Educational Psychological Studies.7(21) 139-150

Al Sharadgah, T. (2014). Developing critical thinking skills through writing in an-internet- based environment. In Society for Information Technology and Teacher Education International Conference (pp. 2178-2185). Association for the Advancement of Computing in Education (AACE).

El-Attar, S. (2013). The Effect of a Suggested Program Based on Discourse Analysis and Metacognitive Awareness on Developing EFL Trainees' Critical Writing Skills and Foreign Language Cultural Awareness. Unpublished doctoral dissertation.Faculty Education. Zagazig University.

Elder, L. (1996). Critical thinking and emotional intelligence. Inquiry:

Critical thinking across the disciplines, 16(2), 35-49. 
El-Maksoud, A., \& El-Fattah, M. A. (2016). The Effect of Using Some Brain-Based Learning Strategies on Developing Journal Writing of English Majors in Basic Education at Faculty of Education, Beni-Suef University. Journal of Research in Curriculum, Instruction and Educational Technology, 41(86), 1- 40.

Bar-On, R. (2006). The Bar-On model of emotional-social intelligence (ESI).Psicothema, 18, 13-25.

Boyatzis, R. E., Goleman, D., \& Rhee, K. (2000). Clustering competence in emotional intelligence: Insights from the Emotional Competence Inventory (ECI). Handbook of emotional intelligence, 99(6), 343-362.

Braun, B. (2014). Personal, expository, critical, and creative: Using writing in mathematics courses. Primus, 24(6), 447-464.

Caine, G., \& Caine, R. N. (2006). Meaningful learning and the executive functions of the brain. The Neuroscience of Adult Learning: New Directions for Adult and Continuing Education, Number 110, 81, 53.

Caine, R. N., Caine, G., McClintic, C., \& Klimek, K. J. (2015). 12 Brain/Mind Learning Principles in Action: Teach for the Development of Higher-Order Thinking and Executive Function: Corwin Press.

Cherniss, C. (2000, April). Emotional intelligence: What it is and why it matters. In annual meeting of the Society for Industrial and Organizational Psychology, New Orleans, LA(Vol. 15).

Duman, B. (2006). The effect of brain-based instruction to improve on students' academic achievement in social studies instruction. Paper presented at the 9th International Conference on Engineering Education, San Juan, Puerto Rico.

Duman, B. (2010). The Effects of Brain-Based Learning on the Academic Achievement of Students with Different Learning Styles. Educational Sciences: Theory and Practice, 10(4), 2077-2103. 
El-Garhy,N.(2016). Enhancing Some Reading Competencies, Comprehension and Reading Literacy Skills for EFL Third Year Preparatory Students through a Brain-Based Strategy. Unpublished doctoral dissertation. Faculty Education. Zagazig University.

Erlauer, L. (2003). The brain-compatible classroom: Using what we know about learning to improve teaching. ASCD.

Ghanizadeh, A., and Moafian, F. (2011). Criticalthinking and emotionalintelligence: Investigating the relationship among EFL learners and the contribution of age and gender. Iranian Journal of Applied Linguistics, 14 (1), $\quad 23-48$

Goleman, D. (1995) Emotional intelligence. New York: Bantam.

Goleman, D. (1998). Working with emotional intelligence. New York: Bantam.

Haghighi, M.(2012).The effect of brain- based learning on Iranian EFL achievement and retention. Akdeniz Language Studies Conference 2012.doi: 10.1016/j.sbspro.2013.01.088 Jackson, W. (2003). The effects of brain-compatible instruction on reading Achievement. Dissertation Abstracts International, 64(09).

Jensen, E. (2000). Brain-based learning. San Diego, CA: The Brain Store

Jensen, E. P. (2008). Brain-based learning: The new paradigm of teaching (2th ed). SanDiego, CA: Corwin Pres

Jensen, E. (2016)"Brain-Based Learning Strategies", $\quad$ Retrieved

from: https://feaweb.org/brain-based-learning-strategies

Karimi,G. (2012). How do productive skills of L2 learning require

EI?In International Conference on Languages, $E$ Learning and Romanian Studies .Romania. 
Koşar, G., \& Bedir, H. (2018). Improving Knowledge Retention Via

Establishing Brain-Based Learning Environment. European Journal of Education Studies

Kruchin,B.,(2016). Improve Your Writing by Studying Critical

Thinking.Retrieved from:

https://learningenglish.voanews.com/a/improve-your-

writing-studying-critical-thinking/3357371.html

Liaw, M. L. (2007). Content-based reading and writing for critical thinking skills in an EFL context. English Teaching and Learning, 31, 45-87.

Marope, P. T. M. (2016). Brain science, education, and learning: Making connections.

Mayer, R. E. (2017). How can brain research inform academic learning and instruction? Educational Psychology Review, 29(4), 835-846.

Prigge, D. J. (2002). Promote brain-based teaching and learning. Intervention in School and Clinic, 37(4), 237-241.

Salar, K., and Oroji, M. R. (2017). Exploring the Relationship between EQ and Intermediate EFL Learners' Speaking Performance: A Gender Study. Journal of Applied Linguistics and Language Research, 4(7), 141-153.

Salovey, P., Woolery, A., and Mayer, J. D. (2001). Emotional intelligence: Conceptualización and measurement. Blackwell handbook of social psychology: Interpersonal processes, 279-307.

Stapleton, P. (2002). Critical thinking in Japanese L2 writing:

Rethinking tired constructs. ELT Journal, 56(3), 250257.

Tate, M. (2013). 20 Instrucional strategies that engage the brain. Instructional Leader. Vol 26 (2),1-3. 
Wang, Y. H. (2009). Incorporating critical thinking skills into an English conversation program. European Journal of Social Sciences, 11(1), 51-60.

Wortock, J. M. M. (2002). Brain based principles applied to the teaching of basic cardiac code to associate degree nursing students using the human patient simulator. Unpublished Doctorate's Theses. University of South Florida. Retrieved January 5, 2005. From Dissertations and Theses Database.

University of Bradford(n.d).Critical analysis when writing.https://www.bradford.ac.uk/...skills/.../academicskill sadvice/.../criticalanalysis/Critical-

Zarezadeh, T. (2013). The effect of emotional intelligence in English language learning. Procedia-Social and Behavioral Sciences, 84, 1286-1289. 


\section{Appendix [1]}

The EFL critical writing test(pre/post)

Name:

Class:

\section{Duration: $80 \mathrm{~m}$}

1- "In Egypt there are many types of schools such as public schools, Formal language schools, Private schools, Japanese schools,..."

Do you think that there should be a variety of schools to satisfy all people and improve the learning process or not? Express your opinion in a short paragraph.

2- "Mobile phones should be banned at schools." Express your point of view in a short paragraph.

3- Do you think that social media like Facebook or Instagram has become a matter of importance in our life today? Support your answer with reasons or evidences.

4- "Some people prefer living in the countryside, others like living in the city."

In a short paragraph, compare between life in the countryside and life in the city.

5- Clarify in a short paragraph what do you think will happen if many people move to live in the city.

6- "Experts think that there are now more than 100 million homeless children on the streets in the world today. This is not a problem only in poor countries. There are also street children in rich countries...."

In a short paragraph clarify the reasons of this phenomena in both of them.

7- In a short paragraph, suggest some solutions to cut down the problem of homeless children. 